Vol.46, n. 4 : pp. 665-671, December 2003 ISSN 1516-8913 Printed in Brazil

\section{BRAZILIAN ARCHIVES OF BIOLOGY AND TECHNOLOGY}

AN INTERNATIONAL JOURNAL

\title{
Temporal Variation in Sargassum Biomass, Hypnea Epiphytism and Associated Fauna
}

\author{
Fosca Pedini Pereira Leite ${ }^{1^{*}}$ and Alexander Turra ${ }^{2}$ \\ ${ }^{1}$ Departamento de Zoologia; IB; fosca@unicamp.br; 13083-970; UNICAMP; Campinas - SP - Brazil. ${ }^{2}$ Programa \\ de Pós-Graduação em Ecologia; turra@unicamp.br; 13083-970; UNICAMP; Campinas - SP - Brazil
}

\begin{abstract}
Studies were carried out to investigate the temporal variation in Sargassum biomass, Hypnea epiphytism and associated fauna. There was a marked variation in the biomass of Sargassum and Hypnea among various sampling periods. Low values for Sargassum were recorded in August and November, while the lower value for Hypnea biomass was recorded in August. An inverse relationship was found between Sargassum biomass and the intensity of Hypnea epiphytism. The density of the total fauna associated to Sargassum showed a marked reduction in May. This variation was influenced by the variation patterns of the dominant faunistic groups (Gastropoda, Gammaridea, Isopoda and Caridea). Significant positive relationships were found between the biomass of Sargassum and Sargassum+Hypnea with the total density of all faunistic groups (per macroalgae biomass unit). However, the influence of Hypnea epiphytism on the phytal organisms was not evidenced.
\end{abstract}

Key words: Sargassum, Hypnea, epiphytism, phytal, associated fauna

\section{INTRODUCTION}

The phytal assemblages show a very diversified composition. The distribution patterns and abundance of species in the phytal demonstrate correlations with the physical characteristics of the macroalgae bed or floating clumps (Coull and Wells, 1983; Stoner and Lewis, 1985), such as turbidity and hydrodynamics (Gibbons, 1988), and sedimentation (Moore, 1973; Gibbons, 1988). The texture and architecture of fronds have been frequently used as measures of macroalgae habitat complexity (Hacker and Steneck, 1990), likewise algae density (Crowder and Cooper, 1982; Stoner and Lewis, 1985), volume (Coull and Wells, 1985) and biomass (Heck and Wetstone, 1977; Stoner and Lewis, 1985).
The presence of epiphytic algae provides an increase in the habitat complexity (Hall and Bell, 1988). These epiphytes are important in structuring the phytal assemblages, contributing to maintain high density and/or diversity of the epifauna by supplying more space and food (Marx and Herrnkind, 1985) or shelter against predators (Crowder and Cooper, 1982; Coull and Wells, 1983; Leber, 1985; Russo, 1987).

Temporal variation in phytal populations can be caused by seasonality in their reproductive activity and recruitment (Edgar, 1983; Dutra, 1988). The seasonality of the epifauna can also be related to the growth and reduction of the macrophytes (Mukai, 1971) and to the variation in epiphytic coverage (Hall and Bell, 1988).

\footnotetext{
* Author for correspondence
} 
Extensive banks of the brown algae Sargassum cymosum occur in the infralittoral fringe on the rocky shores of the State of São Paulo, southeastern Brazil. It is a ramified macroalgae varying from 40 to $60 \mathrm{~cm}$ length (Joly, 1965), which shows seasonal variation in biomass (Paula and Oliveira Filho, 1980). Sargassum is frequently epiphyted by the red algae, Hypnea musciformis in this region (Berchez et al., 1993). This epiphyte has hook-like structures that allow its fixation on the host Sargassum (Joly, 1965).

The aim of this study was to describe the temporal variation in the biomass of Sargassum and the epiphytic Hypnea in four sampling periods over one year. The density of the associated fauna was compared among faunistic groups and periods. The relationship between Sargassum biomass and intensity of Hypnea epiphytism with the abundance of the epifauna was also studied.

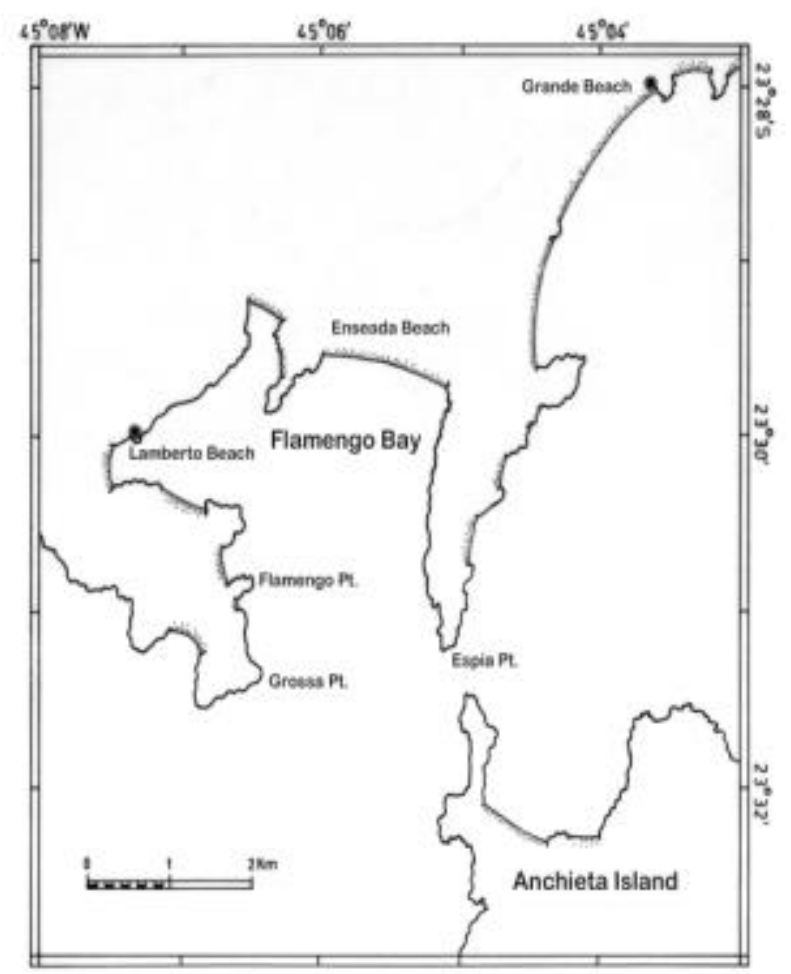

Figure 1 - Map of the northern coast of the State of São Paulo, showing the Lamberto's Beach, Ubatuba, southeastern Brazil

\section{MATERIALS AND METHODS}

This study was carried out on Lamberto's Beach (2330'11's; $\left.45^{\circ} 07^{\prime} 11^{\prime \prime} \mathrm{W}\right)$, located at Flamengo
Bay in the city of Ubatuba (São Paulo, Brazil) (Fig. 1). This small sheltered sandy beach is subjected to semidiurnal tides and has boulders of both natural and anthropic origin where fronds of Sargassum cymosum are attached (Montouchet, 1979).

The collections were taken in February, May, August and November 1989 during diurnal low tide. Ten to fifteen fronds (with the apressory) were removed after the entire frond being covered with a plastic bag. In the laboratory, each frond was washed in a sequence of four buckets filled with seawater and drops of formalin to remove the fauna. This method is considered efficient and removes $95 \%$ of the total epifauna (Taylor and Cole, 1994). The water from the buckets was filtered through sieves of $0.295 \mu \mathrm{m}$ mesh size to retain the macrofauna and juveniles (Tanaka and Leite, 1998). The material was fixed in $70 \%$ alcohol. The epiphyte Hypnea was carefully removed from the Sargassum fronds and both algae were dried at $80^{\circ} \mathrm{C}$ for 12 hours to determine their dry weight. Statistical analyses were based on Zar (1984), with the significance level set at 0.05 . Kruskal-Wallis test was used to compare Sargassum biomass, intensity of Hypnea epiphytism [percentage of Hypnea biomass (dry weight) in the total epiphyted macroalgae frond biomass (Hypnea+Sargassum)], and densities of the fauna among sampling periods. A nonparametric Tukey-type test was performed to address the pairwise comparisons among dates (Zar, 1984). The relationship between Sargassum biomass and intensity of Hypnea epiphytism was estimated by regression analysis. The abundance of the total fauna (total number of individuals) was also correlated with biomass of Sargassum, biomass of Sargassum+Hypnea, and intensity of epiphytism by Hypnea.

\section{RESULTS}

Variation in Sargassum biomass and in intensity of Hypnea epiphytism

There was a marked variation in the mean frond biomass of Sargassum among the sampling dates (Kruskal-Wallis, $\mathrm{H}=45.81, \mathrm{df}=3, \mathrm{p}<0.001$ ) with smaller values being recorded in August and November (Fig. 2, see Tukey-type test). Seasonal variation in the biomass of Hypnea was also significant $(\mathrm{H}=12.45, \mathrm{df}=3, \mathrm{p}=0.006)$ with the 
lowest value in August. The intensity of Hypnea epiphytism fluctuated during the study period $(\mathrm{H}=11.38, \mathrm{df}=3, \mathrm{p}=0.001)$, following the seasonal pattern of Sargassum, except in November (Fig. 2, see Tukey-type test). In this month, the frequency of Hypnea epiphytism was higher when compared to the absolute lower biomass of Sargassum.

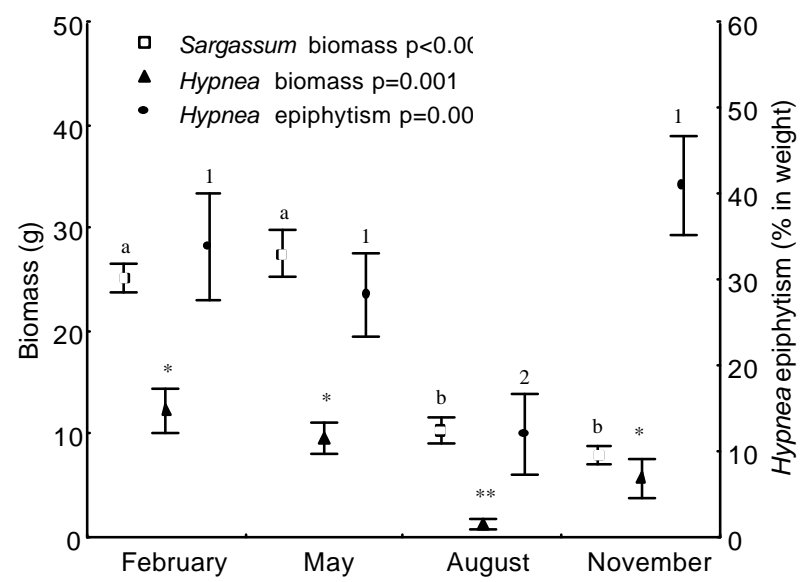

Figure 2 - Biomass (g) of Sargassum and Hypnea and intensity of Hypnea epiphytism (\% in weight) in four sampling periods in Lamberto's Beach, Ubatuba, Brazil, in 1989. Superscript figures indicate the results of the non-parametric Tukey-type multiple pair-wise compa-risons.

About $30 \%$ of the fronds of Sargassum were not epiphyted by Hypnea during the whole sampling period. In order to verify the relationship between Sargassum biomass and Hypnea epiphytism, Sargassum fronds from February and May were selected due to their similar weights (Fig. 2). Fronds from August and November were not considered in this analysis because they had lower biomass in relation to February and May, the small variation in their biomass, and the marked variation in the intensity in the intensity of Hypnea epiphytism (Fig. 3). Sargassum fronds without the epiphyte were also not taken into account in this analysis. These two procedures were done to avoid confounding effects of seasonality in the Sargassum biomass and differential colonization of epiphytes among individual fronds in estimating the relationship between Sargassum biomass and intensity of Hypnea epiphytism. Such procedure evidenced an inverse relationship between these two parameters $\left(\mathrm{r}^{2}=0.770, \quad \mathrm{df}=1, \quad \mathrm{p}<0.001\right.$; $y=59.219-0.877 x)($ Fig. 3).

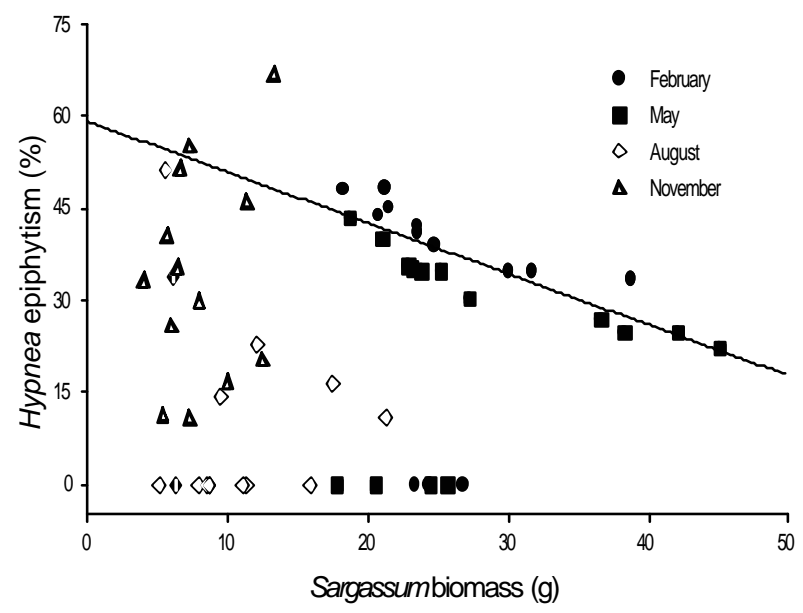

Figure 3 - Relationship between the biomass of Sargassum (g) and the intensity of epiphytism (\%) by Hypnea. The linear model was fitted for the points from February and May not considering those points where the intensity of Hypnea epiphytism was null.

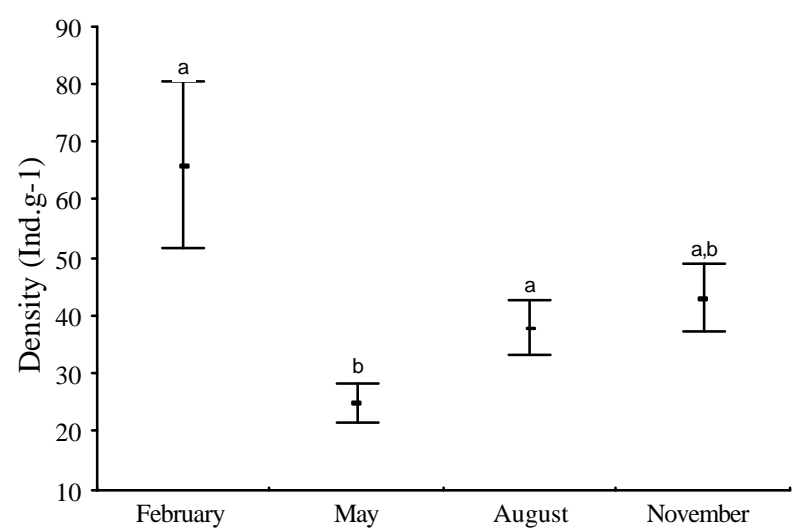

Figure 4 - Density (ind.g ${ }^{-1}$ ) of the total fauna associated to Sargassum in the sampling periods. Superscript figures indicate the result of the non-parametric Tukey-type multiple pairwise comparisons.

\section{Temporal variation of faunistic composition}

Gastropoda dominated the fauna and was followed by Gammaridea, Caridea and Isopoda. The other faunistic groups occurred in lower densities. A marked seasonal variation in the mean density of the almost all faunistic groups associated to Sargassum was found among sampling dates (Table 1). This variation was also recorded for the total fauna, i.e., when all individuals of all 
faunistic groups were pooled in the same analysis (Fig. 4). Highest and lowest mean densities were observed in February and May, respectively (Tukey-type test in Fig. 4). Gammaridea, Caprellidea and Polychaeta (Fig. 5, see Tukey-type test), as well as Polycladida and Tanaidacea showed an increase in density from February to November. The gastropods showed an opposite pattern with a reduction in density from February to November. Isopoda and Caridea (Fig. 5) as well as Anthozoa and Brachyura did not show a clear temporal pattern. Bivalvia, Pycnogonida, Anomura, Mysidacea, Holothuroidea, Nudibranchia and Pisces did not show any variation over the year.

\section{Relationship between algae and faunistic composition}

Strong positive relationships were observed between the frond biomass of Sargassum and Sargassum+Hypnea with the total abundance of the total fauna (variables $\log$ transformed; $n=57$, $\mathrm{r}^{2}=0.415, \mathrm{p}<0.001, \mathrm{y}=3.466+0.990 \mathrm{x} ; \mathrm{n}=57$, $\mathrm{r}^{2}=0.457, \mathrm{p}<0.001, \mathrm{y}=3.383+0.922 \mathrm{x}$, respectively). No relationship was found between the Hypnea epiphytism (considering only the epiphyted fronds) and the abundance of the total fauna (variables $\log$ transformed; $\mathrm{n}=40, \mathrm{r}^{2}=0.008, \mathrm{p}=0.589$ ).

\section{DISCUSSION}

The epiphytism by Hypnea showed a direct relationship with Sargassum biomass during the study period. From August to November, the epiphytism rate increased considerably but this trend was not followed by an increase into Sargassum biomass. Moreover, there was a significant and inverse relationship between individual biomass of Sargassum fronds and the intensity of Hypnea epiphytism taking in account periods of the year with similar values of Sargassum biomass (February and May) (Fig. 3).

The larger (heavier) the fronds of Sargasssum, the smaller the intensity of Hypnea epiphytism they seem to sustain. Differences in sizes of the fronds could be related to the influence of the epiphytic algae over the growth and survival of the macroalgae substratum. Epiphytes may reduce the photosynthetic rates of the macroalgae and increase branch fragmentation (Buschmann and Gomez, 1993).

As several species of filamentous epiphytic algae grow especially in the uppermost portion of the branches, they may promote the loss of those portions (Széchy and Paula, 1998). Since Hypnea epiphytism on Sargassum is very frequent in the studied area, this epiphyte may influence the development of this macroalgae.

Table 1 - Mean density (ind. ${ }^{-1} ; \pm$ SD, Standard deviation; overall mean using temporal samples as replicates) of the fauna associated to Sargassum. Kruskal-Wallis $(\mathrm{H})$ test was used to compare the density of each faunistic group among the sampling periods $(n=4)$.

\begin{tabular}{lccc}
\hline Taxonomic Group & Mean $\#$ SD & H & p \\
\hline Gastropoda & $21.80 \pm 18.05$ & 20.349 & $<0.001$ \\
Gammaridea & $3.55 \pm 5.20$ & 47.660 & $<0.001$ \\
Caridea & $2.25 \pm 6.26$ & 12.059 & 0.007 \\
Isopoda & $1.28 \pm 2.30$ & 42.100 & $<0.001$ \\
Caprellidea & $0.77 \pm 2.05$ & 37.234 & $<0.001$ \\
Polychaeta & $0.63 \pm 1.09$ & 31.686 & $<0.001$ \\
Polycladida & $0.06 \pm 0.11$ & 12.538 & 0.006 \\
Nudibranchia & $0.05 \pm 0.28$ & 3.133 & 0.372 \\
Tanaidacea & $0.05 \pm 0.15$ & 17.801 & $<0.001$ \\
Anthozoa & $0.04 \pm 0.12$ & 22.101 & $<0.001$ \\
Pycnogonida & $0.03 \pm 0.06$ & 4.358 & 0.225 \\
Brachyura & $0.03 \pm 0.06$ & 8.739 & 0.033 \\
Anomura & $0.02 \pm 0.05$ & 5.339 & 0.149 \\
Bivalvia & $0.01 \pm 0.02$ & 2.821 & 0.420 \\
Ostracoda & $0.01 \pm 0.01$ & 8.827 & 0.032 \\
Holothuroidea & $0.01 \pm 0.04$ & 0.933 & 0.818 \\
Pisces & $0.01 \pm 0.02$ & 3.026 & 0.388 \\
Total Fauna & $30.57 \pm 20.78$ & 11.875 & 0.008 \\
\hline
\end{tabular}

Only one individual of Mysidacea was recorded 


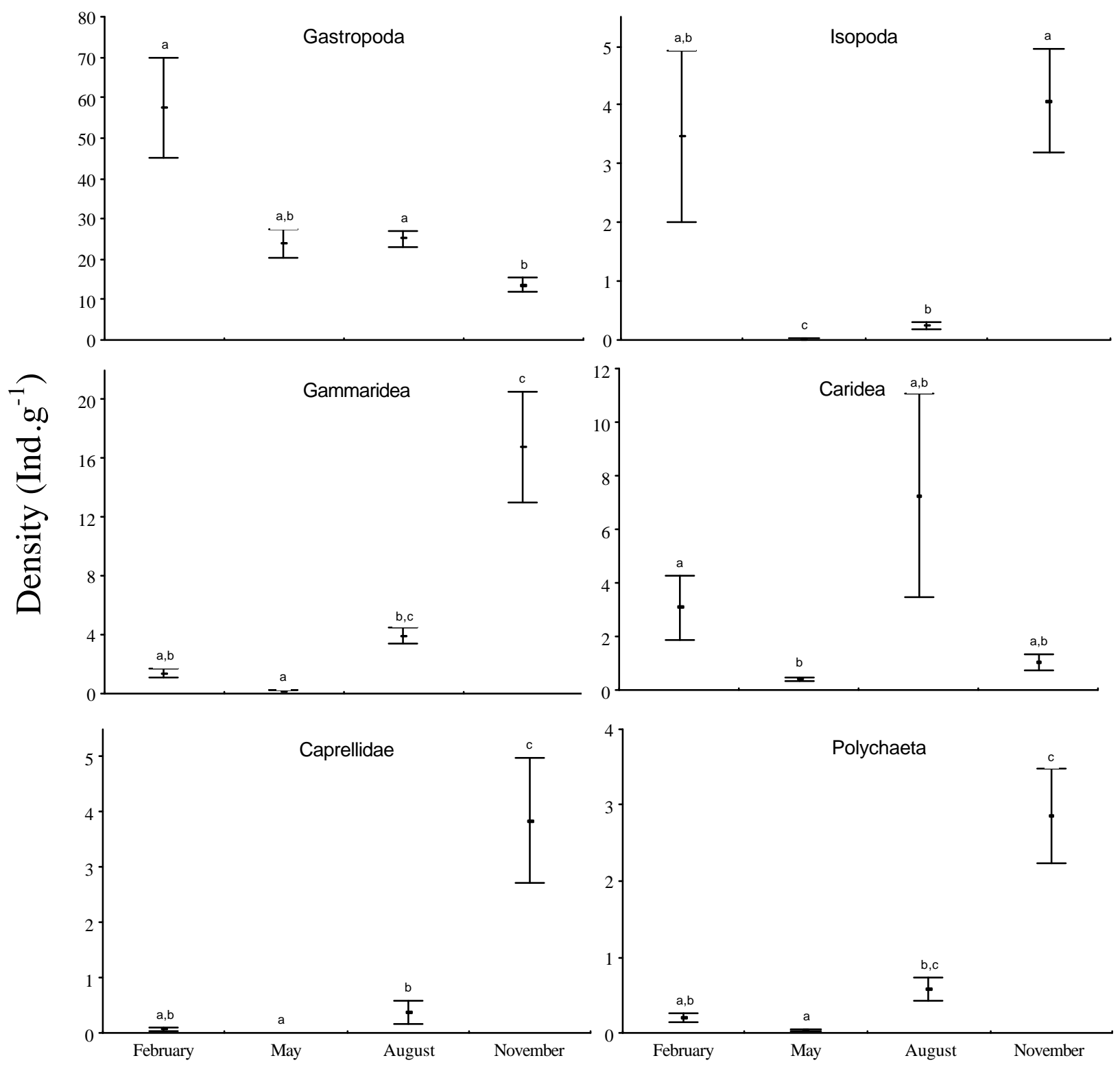

Figure 5 - Density (ind. $\mathrm{g}^{-1}$ ) of the most abundant groups of the fauna associated to Sargassum in the sampling periods. Superscript figures indicate the result of the non parametric Tukey-type multiple pair-wise comparisons.

Hypnea biomass showed a temporal variation with smaller values recorded in August. This pattern did not support the results of Faccini and Berchez (2000), which did not find evidence for temporal variation in biomass of Hypnea on the coast of São Paulo State. On the other hand, the temporal variation in Sargassum biomass, with higher values in summer (February) and lower values in winter (August), agreed with previous studies in the same region (Paula and Oliveira Filho, 1980).
The associated fauna of Sargassum at Lamberto's Beach was found to be dominated by Gastropoda. Gammaridea and Caridea were also very representative groups in the Sargassum fronds in this study. In fact, Gastropoda and Gammaridea were frequently described as dominant groups on phytal assemblages both in Lamberto's Beach (Montouchet, 1979; Tararam and Wakabara, 1981) as well as in other areas (Dutra, 1988). Caridea and Isopoda have also been recorded in high densities associated to this algae (Tararam and 
Wakabara, 1981; Mantellato et al., 1999). The other faunistic groups occurred in low densities and sometimes were rare as also described by Tararam and Wakabara (1981). However, the low density of some groups such as Brachyura, Anomura and Pisces could be caused by an inadequacy of the sampling method (covering the algae with plastic bags in low tides) in estimating abundance of very mobile organisms.

The density of some faunistic groups associated with Sargassum showed a clear variation over the studied period. The increase in density of some groups from February to November could have been caused by different factors: 1 . recruitment peaks; 2. reduction in biomass of Sargassum without reduction in species abundance; 3. migration related to the high complexity offered by the high Hypnea epiphytism in November. The inverse pattern, i.e., reduction in density starting in February, could be explained by the reduction in Sargassum biomass, associated with an increase in the intensity of Hypnea epiphytism, which reduced the available surface to be used by the organisms. This would be especially applied to the gastropods, which needed large surfaces to attach to or feed on. The increase in the intensity of Hypnea epiphytism might positively influence the density of amphipods (both gammarid and caprellid) due to an increase in habitat complexity. In fact, a positive relationship between habitat complexity and abundance of amphipods was observed (Martin-Smith, 1993).

Macroalgae biomass may influence the density of organisms of the phytal assemblages as also demonstrated in the present study (Stoner and Lewis, 1985). In addition, the presence of epiphytes directly influenced the species density (Martin- Smith, 1993; Pavia et al., 1999) by increasing the structural complexity and food availability (Stoner and Lewis, 1985; Sebens, 1991; Jarvis and Seed, 1996). The influence of the frequency of epiphytism on the density of taxonomic groups was not evidenced at Lamberto's Beach. However, it did not refute the positive effect of Hypnea epiphytism demonstrated on particular functional groups as herbivores (Poore, 1994; Viejo, 1999) and tube building species (Schneider and Mann, 1991).

\section{ACKNOWLEDGMENTS}

The authors would like to thank CNPq (Proc. $\mathrm{N}^{0}$ 300337/82-5) and FAEP for the fellowship to F. P. P. Leite, and to A. Z. Güth for the valuable comments on the manuscript.

\section{RESUMO}

Sargassum cymosum é uma alga muito freqüente e abundante no sudeste do Brasil a qual apresenta uma fauna associada muito diversificada $e$ freqüentemente epifitada pela alga vermelha Hypnea musciformis. Foram realizadas quatro amostragens na Praia do Lamberto, litoral norte do Estado de São Paulo, para observar a variação temporal da biomassa de Sargassum, do epifitismo de Hypnea e da fauna associada. Observou-se uma marcada variação da biomassa de Sargassum e Hypnea entre os períodos de amostragem. Os menores valores para Sargassum foram obtidos em agosto e novembro, enquanto o menor valor para Hypnea foi obtido em agosto. Relação inversa foi observada entre a biomassa de Sargassum e o epifitismo de Hypnea. A densidade da fauna total associada a Sargassum também mostrou variação significativa entre os períodos de amostragem, com marcada redução em maio. Este padrão foi influenciado pela variação dos grupos taxonômicos dominantes (Gastropoda, Gammaridea, Isopoda e Caridea). Observou-se uma forte relação positiva entre a biomassa of Sargassum e Sargassum+Hypnea com a abundância de todos os grupos taxonômicos. Contudo, não ficou evidenciada a influência do epifitismo de Hypnea sobre os organismos do fital.

\section{REFERENCES}

Berchez, F. A. S.; Pereira, R. T. L. and Kamiya, N. F. (1993), Culture of Hypnea musciformis (Rhodophyta, Gigartinales) on artificial substrates attached to linear ropes. Hydrobiologia, 261, 415-420.

Buschmann, A. H. and Gomez, P. (1993), Interaction mechanisms between Gracilaria chilensis (Rhodophyta) and epiphytes. Hydrobiologia, 261, 345-351.

Coull, B. C. and Wells, J. B. (1983), Refuges from fish predation: experiments with phytal meiofauna from the New Zealand rocky intertidal. Ecology, 64, 1599-1609.

Crowder, L. B. and Cooper, W. E. (1982), Habitat structural complexity and the interaction between bluegills and their prey. Ecology, 63, 1802-1813. 
Dutra, R. R. C. (1988), A fauna vágil do fital de Pterocladia capillacea (Rodophyta, Gelidiaceae) da Ilha do Mel, Paraná, Brasil. Rev. Bras. Biol., 48, 589-605.

Edgar, G. J. (1983), The ecology of southeast Tasmanian phytal animal communities. II. Seasonal change in plant and animal populations. J. Exp. Mar. Biol. Ecol., 70, 159-179.

Faccini, A. L. and Berchez, F. A. S. (2000), Management of natural beds and standing stock evaluation of Hypnea musciformis (Gigartinales, Rhodophyta) in south-eastern Brazil. J. Appl. Phycol., 12, 101-103.

Gibbons, M. J. (1988), The impact of wave exposure on the meiofauna of Gelidium pristoides (Turner) Kuetzing (Gelidiales: Rodophyta). Est. Coast. Shelf Sci., 27, 581-593.

Hacker, S. D. and Steneck, R. S. (1990), Habitat architecture and body-size-dependent habitat selection of a phytal amphipod. Ecology, 71, 2269-2285.

Hall, M. O. and Bell, S. S. (1988), Response of motile epifauna to complexity of epiphytic algae on seagrass blades. J. Mar. Res., 46, 613-630.

Jarvis, S. C. and Seed, R. (1996), The meiofauna of Ascophyllum nodosum (L) Le Jolis: Characterization of the assemblages associated with two common epiphytes. J. Exp. Mar. Biol. Ecol,. 199, 249-267.

Joly, A. B. (1965), Flora marinha do litoral norte do estado de São Paulo e regiões circunvizinhas. Bol. Fac. Fil. Ciências e Letras da U. S. P., 294. Botânica, 21, 1-393.

Leber, K. M. (1985), The influence of predatory decapods, refuge, and microhabitat selection on seagrass communities. Ecology, 66, 1951-1964.

Mantelatto, F. L. M., Martinelli, J. M. and Garcia, R. B. (1999), Fecundity of Hippolyte obliquimanus Dana, 1852 (Decapoda, Caridea, Hippolytidae) from the Ubatuba region, Brazil. In: Schram, F. R. and von Vaupel Klein, J. C. (eds). Crustaceans and the Biodiversity Crisis. J. Brill. Leiden.

Marx, J. and Herrnkind, W. (1985), Factors regulating microhabitat use by young juvenile spiny lobster, Panulurus argus: food and shelter. J. Crust. Biol., 5, 650-657.

Martin-Smith, K. M. (1993), Abundance of mobile epifauna: the role of habitat complexity and predation by fishes. J. Exp. Mar. Biol. Ecol., 174, 243-260.

Montouchet, P. G. C. (1979), Sur la communauté des animaux vagiles associés à Sargassum cymosum $\mathrm{C}$. Agardh, à Ubatuba, Etat de São Paulo Brésil. Stud. Neotrop. Fauna Env., 18, 151-161.

Moore, P.G. (1973), The larger Crustacea associated with holdfasts of kelp (Laminaria hyperborea) in North-East Britain. Cah. Biol. Mar., 14, 493-518.

Mukai, H. (1971), The phytal animals on the thalli of Sargassum serratifolium in the Sargassum region, with reference to their seasonal fluctuations. Mar. Biol., 8 170-182.
Paula, E. J. and Oliveira Filho, E. C. (1980), Phenology of two populations of Sargassum cymosum (Phaeophyta - Fucales) of São Paulo State coast, Brazil. Bol. Bot., 8, 21-39.

Pavia, H., Carr, H. and Aberg, P. (1999), Habitat and feeding preferences of crustacean mesoherbivores inhabiting the brown seaweed Ascophyllum nodosum (L.) Le Jol. and its epiphytic macroalgae. J. Exp. Mar. Biol. Ecol., 236, 15-32.

Poore, A. G. B. (1994), Selective herbivory by amphipods inhabiting the brown alga Zonaria angustata. Mar. Ecol. Prog. Ser., 107, 113-123.

Russo, A. R. (1987), Role of habitat complexity in mediating predation by the gray damselfish Abudefduf sordidus on epiphytal amphipods. Mar. Ecol. Progr. Ser., 36, 380-396.

Scheneider, F. I. and Mann, K. H. (1991), Species especific relationships of invertebrates to vegetation in a seagrass bed. II. Experiments on the importance of macrophyte shape, epiphyte cover and production. J. Exp. Mar .Biol. Ecol., 145, 119-139.

Sebens, K. P. (1991), Habitat structure and community dynamics in marine benthic systems. In: S. S. Bell, E. D. McCoy and Mushinsky, H. R. (eds), Habitat structure: The Physical Arrangement of Objects in Space. Chapman and Hall. London.

Stoner, A. W. and Lewis, F .G. (1985), The influence of quantitative aspects of habitat complexity in tropical seagrass meadows. J. Exp. Mar. Biol. Ecol., 94, 19-40.

Széchy, M. T. M. and Paula, E. J. (1998), Tipos morfológicos em populações de Sargassum (Phaeophyta-Fucales) do litoral dos Estados do Rio de Janeiro e São Paulo, Brasil. Leandra, 13, 29-43.

Tanaka, O. M. and Leite, F. P. P. (1998), The effect of sieve mesh size on the abundance and composition of macrophyte-associated macrofaunal assemblages. Hydrobiologia, 389, 21-28.

Tararam, A. S., and Wakabara, Y. (1981), The mobile fauna-especially Gammaridea-of Sargassum cymosum. Mar. Ecol. Prog. Ser., 5, 157-163.

Taylor, R. B. and Cole, R. G. (1994), Mobile epifauna on subtidal brown seaweeds in northeastern New Zealand. Mar. Ecol. Prog. Ser., 115, 271-282.

Viejo, R. M. (1999), Mobile epifauna inhabiting the invasive Sargassum muticum and two local seaweeds in northern Spain. Aquat. Bot., 64, 131-149.

Zar, J. H., 1984, Biostatistical Analysis. Prentice-Hall, $2^{\text {nd }}$ ed. 718 pp.

Received: September 11, 2001; Revised: April 30, 2002; Accepted: August 26, 2002. 